\title{
Technological Restrictions at 3D Printing with Zortrax M200 3D Printer
}

\author{
EMANUEL R. BOGDAN SCUTARU, Transilvania University of Brașov, \\ Faculty of Technological Engineering \\ Professional paper \\ and Industrial Management, Brașov, Romania \\ UDC: 681.625.9:004.356.2 \\ GEORGIANA G. VETRICE, Transilvania University of Brașov, \\ Faculty of Technological Engineering \\ and Industrial Management, Brașov, Romania \\ IVAN V. KNEŽEVIĆ, University of Novi Sad, \\ Faculty of Technical Sciences, Novi Sad \\ MIRCEA $V$. VIOREL DR $\breve{A G O I, ~ T r a n s i l v a n i a ~ U n i v e r s i t y ~ o f ~ B r a s ̦ o v, ~}$ \\ Faculty of Technological Engineering \\ and Industrial Management, Brașov, Romania \\ VALENTIN C. MARIAN STAMATE, Transilvania University of Brașov, \\ Faculty of Technological Engineering \\ and Industrial Management, Brașov, Romania
}

\begin{abstract}
The aim of the research presented in this paper is to examine the accuracy (to what extent the $3 D$ print fits to the 3D model) and the precision (which establishes the consistency of the measurements) for smallsized plastic parts printed on Zortrax M200 3D printer. One of the goals of the research is to find out how much the thickness of a wall (or of a bolt) can be reduced as it still to keep its stiffness and dimensional precision. A proper method for designing part couples was targeted. In order for a part to be correctly assembled with its pair, the deviation of the physical dimensions was taken into account. Also, the results of the experimental work on the capabilities and limitations of printing technology using this printer are presented in this paper. Several parameters such as surface quality and strength, layer shifting or misalignment are closely studied.
\end{abstract}

Key words: $3 D$ printing, technological restrictions, fused deposition modeling, Zortrax M200, smallsized parts, technological restrictions

\section{INTRODUCTION}

Almost forty years into its development, additive manufacturing (AM), also known as 3D printing, has become a mainstream manufacturing process, already widely applied to many industries.

Additive manufacturing is a manufacturing method which builds up parts by deposing materials, such as plastic or metal, onto one another in layers based on a computerized 3D solid model. This model can dire

Author's address: Emanuel Bogdan Scutaru, Transilvania University of Brașov, Faculty of Technological Engineering and Industrial Management, Braşov, B-dul Eroilor nr. 29, Romania

e-mail: scutaru.bogdan92@gmail.com

Paper received: 25.01.2019.

Paper accepted: 19.03.2019. ctly be transformed to a finished part without the use of additional machining or cutting tools $[1,2]$.

Complexity and design freedom, customization, efficiency and material waste minimization are the main benefits of 3D printing. As such, too much attention should not be paid to design for manufacturing and assembly (DFM/DFA) while designing the product, which is conducive to design innovation.

In order to take advantages of the above-mentioned benefits of 3D printing, it is necessary to consider the manufacturing limits and restrictions of this new technology. Although a considerable number of papers regarding additive manufacturing have been published over the past four decades, most of them were focused on different processing technologies.

The purpose of this paper is to assess the accuracy and the precision for small-sized parts printed on 
Zortrax M200 3D printer. Information is gathered, analyzed and summarized in order to draw conclusions regarding the capabilities and restrictions of the technology when printing small-sized parts. The study was carried out at the Department of Manufacturing Engineering of Transilvania University of Brașov.

\section{ADDITIVE MANUFACTURING TECHNOLOGY}

In order to obtain a part using additive manufacturing technology the following steps must be performed [2]:

1. A computerized 3D solid model must be produced. The most common method is computer-aided design (CAD), but reverse engineering can also be used to produce a digital model via 3D scanning. The 3D model will be converted into an STL (stereolithography) file format, which describes only the surface geometry of the 3D model, using polygons, without any other CAD attributes or into a recent additive manufacturing file format.

2. Once the STL file has been generated, it is sent to a slicer, a specialized computer software that allows manipulating the model in order to change (if needed) its position and orientation, or scaling it. Also, during this step the build parameters will be customized, such as support or layer height. Afterwards, the slicer creates a G-code file, which is sent to an additive manufacturing machine.

3 . The part is built on the additive manufacturing machine using layer-by-layer fabrication technique.

There are several methods of 3D printing, but the most widely used for plastic materials is Fused Deposition Modeling (FDM), an additive manufacturing process that belongs to the material extrusion family.

In FDM, the object is built by extruding melted thermoplastic material from a movable FDM head and then selectively depositing it in ultra-thin layers onto a substrate. The material comes in a filament shape and is heated slightly above its melting point so that it solidifies almost immediately after extrusion and cold welds onto the previous layer [2].

As for any technology, 3D printing has some fundamental limitations and rules that need to be followed [3]. Before starting the manufacturing process, technological restrictions (in terms of size and geometry) must be considered, in order to determine whether a $3 \mathrm{D}$ model is suitable for $3 \mathrm{D}$ printing. These considerations apply to all CAD designs, from basic parts to more complex components.

Further on, the most important restrictions will be presented, which were taken into account in this study as well. The first one that should be taken into account is the physical size. It is impossible to $3 \mathrm{D}$ print thin parts or sections of a design that are smaller than the minimum printable feature size for each technology. FDM recommends a minimum size of $0.8 \mathrm{~mm}$. For larger parts, the model can be split into 2 or more parts that can be printed separately and later assembled. The second most important aspect is watertightness. The model should be completely watertight: without any gaps between faces and edges. Otherwise, inconsistent layers, holes or other errors may occur, making the object unprintable [4].

Although as a printing technology FDM is very flexible, the manufacturing of parts is not limited by shape, but it is limited by dimension [5]. Therefore, this research is conducted to determine the precision and accuracy of small-sized parts using this technology.

\section{MATERIAL AND METHOD}

For this study twelve benchmark models of different sizes with various shapes (all in vertical position) are considered.

A good variety of materials can be used, but in this study the basic 3D printing filament Z-ABS (Z-Acrylonitrile butadiene styrene) was selected, due to its characteristics: high quality, easy post-processing and mat surface. The main technical properties of Z-ABS are presented in Table 1 [6].

\section{Table 1. Technical properties of Z-ABS material [6]}

\begin{tabular}{|l|l|}
\hline Mechanical Properties & Metric \\
\hline Tensile Strength & $30.46 \mathrm{MPa}$ \\
\hline Breaking Stress & $25.89 \mathrm{MPa}$ \\
\hline $\begin{array}{l}\text { Elongation at max Tensile } \\
\text { Stress }\end{array}$ & $4.52 \%$ \\
\hline Elongation at Break & $11.08 \%$ \\
\hline Bending Stress & $46.30 \mathrm{MPa}$ \\
\hline Flexural Modulus & $1.08 \mathrm{GPa}$ \\
\hline Izod Impact, Notched & $8.93 \mathrm{~kJ} / \mathrm{m}^{2}$ \\
\hline Thermal Properties & Metric \\
\hline Glass Transition Temperature & $107.89^{\circ} \mathrm{C}$ \\
\hline
\end{tabular}

The device used for manufacturing is a desktop 3D printer based on FDM technology, Zortrax M200 (Zortrax, Poland). The specifications are shown in Figure 1.

The set of parameters used for printing the parts is: layer thickness of $0.14 \mathrm{~mm}$, high quality, auto fan speed, normal seam, 4 top and 4 bottom surface layers. Infill is a very important factor to a print's strength, weight and decorative properties. The term refers to the structure that is printed inside an object. The higher the infill percentage, the stronger the print. For this survey two infill percentages were considered: each part was printed twice, once with $60 \%$ infill and 
secondly with $100 \%$ infill. Same parameters presented above were used for both infill percentages.

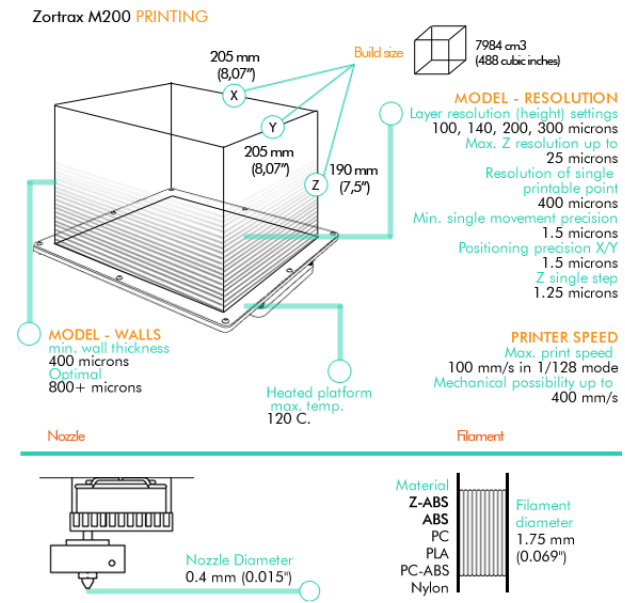

Figure 1 - Schematic presentation and the main technical details of Zortrax M200 3D printer [7] below.

The models considered for printing are presented

The model illustrated in Figure 2 a. is a cylindrical part which can be assembled with the part in Figure 2 b. It was printed for diameter $e$ of $15 \mathrm{~mm}$, height $h$ of $16.5 \mathrm{~mm}$, height 1 of $15 \mathrm{~mm}$ and diameter $d$ of $12 \mathrm{~mm}$, $11.9 \mathrm{~mm}, 11.8 \mathrm{~mm}$ and $11.7 \mathrm{~mm}$.

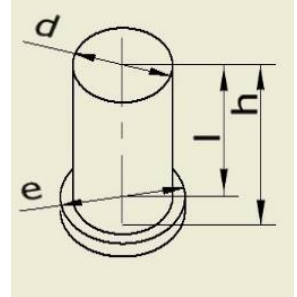

a)

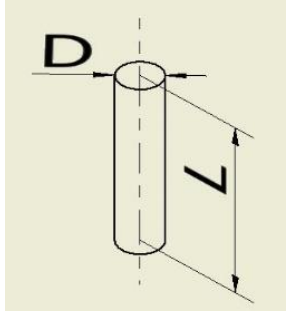

e)

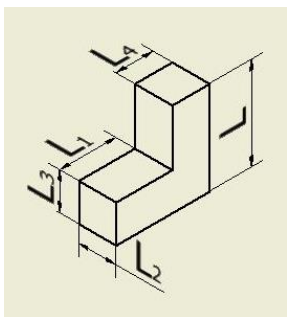

i)

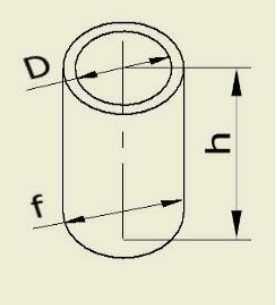

b)

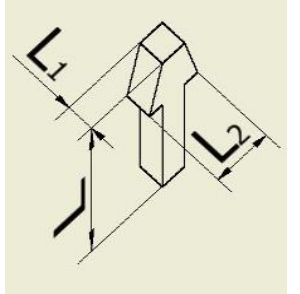

f)

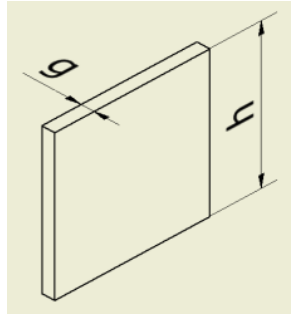

j)
The model presented in Figure 2 b. is a small tube printed for dimeter $\mathrm{f}$ of $15 \mathrm{~mm}$, diameter $\mathrm{D}$ of $12 \mathrm{~mm}$ and height h of $16.5 \mathrm{~mm}$. The model shown in Figure 2 c. can be assembled with the part from Figure $2 \mathrm{~d}$. It was printed for diameter $\mathrm{d}$ of $15 \mathrm{~mm}$, height $\mathrm{h}$ of 16.5 $\mathrm{mm}$ and length 1 of $9 \mathrm{~mm}, 8.9 \mathrm{~mm}, 8.8 \mathrm{~mm}, 8,7 \mathrm{~mm}$, $8.6 \mathrm{~mm}$ and $8.5 \mathrm{~mm}$. The model pictured in Figure $2 \mathrm{~d}$. was printed for diameter d of $15 \mathrm{~mm}$, length $\mathrm{f}$ of 12.99 $\mathrm{mm}$, length L of $8.99 \mathrm{~mm}$ and height h of $16.5 \mathrm{~mm}$.

The two pairs mentioned above were closely studied in order to determine the way they can be correctly fitted. In this regard, for each part its pair was printed three times in order to find the optimal match between them. The model shown in Figure 2 e. is a cylindrical part which was printed in different sizes: diameters of $3 \mathrm{~mm}, 4 \mathrm{~mm}, 5 \mathrm{~mm}, 6 \mathrm{~mm}$ and lengths of $15 \mathrm{~mm}, 20 \mathrm{~mm}$ and $25 \mathrm{~mm}$.

The model represented in Figure $2 \mathrm{f}$. was printed for length $\mathrm{L}$ of $15 \mathrm{~mm}$, length $\mathrm{L}_{1}$ of $5 \mathrm{~mm}$ and length $\mathrm{L}_{2}$ of $7.68 \mathrm{~mm}, 8.64 \mathrm{~mm}, 9.66 \mathrm{~mm}$ and $10.77 \mathrm{~mm}$.

The model presented in Figure $2 \mathrm{~g}$. was printed for length $\mathrm{L}$ of $154 \mathrm{~mm}$ and $152 \mathrm{~mm}$, length $\mathrm{L}_{1}$ of $15 \mathrm{~mm}$ and thickness $\mathrm{G}$ of $1 \mathrm{~mm}$ or $2 \mathrm{~mm}$.

The model illustrated in Figure $2 \mathrm{~h}$. was printed for diameter $\mathrm{D}$ of $10 \mathrm{~mm}$, diameter $\mathrm{D}_{1}$ of $22 \mathrm{~mm}$, length $\mathrm{L}$ of $17 \mathrm{~mm}$ and length $\mathrm{L}_{1}$ of $15 \mathrm{~mm}$.

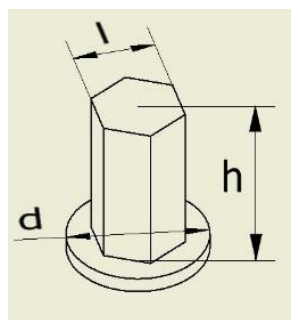

c)

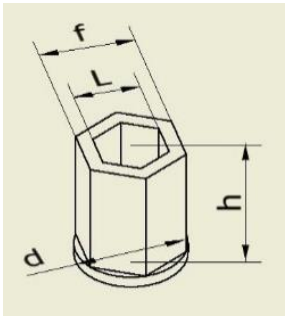

d)

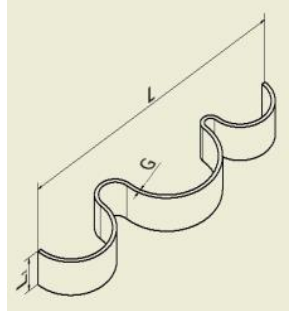

g)

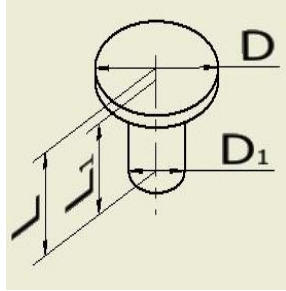

h)

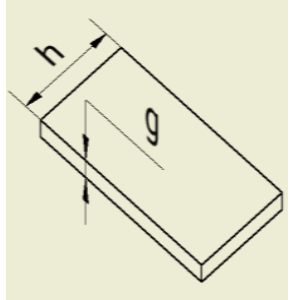

k)

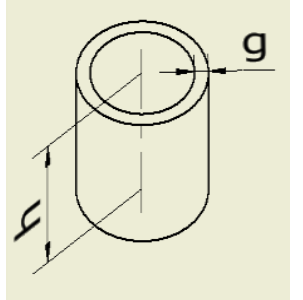

l)

Figure 2-Models considered for printing 
The model represented in Figure 2 i. has a parallelepiped shape and was printed for length $\mathrm{L}$ of 25 $\mathrm{mm}$, length $\mathrm{L}_{1}$ of $15 \mathrm{~mm}$, length $\mathrm{L}_{2}$ of $10 \mathrm{~mm}$, length $\mathrm{L}_{3}$ of $10 \mathrm{~mm}$ and length $\mathrm{L}_{4}$ of $10 \mathrm{~mm}$. The model shown in Figure $2 \mathrm{j}$. is a plate printed for height $\mathrm{h}$ of 15 $\mathrm{mm}$ and $30 \mathrm{~mm}$ and a thickness $\mathrm{g}$ of $0.5 \mathrm{~mm}, 0.75 \mathrm{~mm}$, $1 \mathrm{~mm}, 1.25 \mathrm{~mm}, 1.5 \mathrm{~mm}, 1.75 \mathrm{~mm}, 2 \mathrm{~mm}, 2.25 \mathrm{~mm}$ and $2.5 \mathrm{~mm}$. The model pictured in Figure $2 \mathrm{k}$. was printed for height $\mathrm{h}$ of $15 \mathrm{~mm}$ and thickness $\mathrm{g}$ of 0.5 $\mathrm{mm}, 0.75 \mathrm{~mm}, 1 \mathrm{~mm}, 1.25 \mathrm{~mm}, 1.5 \mathrm{~mm}, 1.75 \mathrm{~mm}$ and $2 \mathrm{~mm}$. The model illustrated in Figure 21 . is a small tube which was printed for height $\mathrm{h}$ of $15 \mathrm{~mm}$ and thickness g of $0.5 \mathrm{~mm}, 0.75 \mathrm{~mm}, 1 \mathrm{~mm}, 125 \mathrm{~mm}, 1.5$ $\mathrm{mm}, 1.75 \mathrm{~mm}$ and $2 \mathrm{~mm}$

\section{RESULTS AND DISCUSSIONS}

Accuracy is how close a measured dimension is to its true value (designed in CAD) and precision expresses the repeatability of a measurement. Further on, the results of the measurements are presented. Tables 2-5 summarize the values that came out for the two pairs studied. Each value is the arithmetical mean of ten measurements at different points. These ten measurements determine also the precision of the measurements, which was evaluated as high and low (high when the consistency of a measurement was above the average and low when it was below the average).

Table 2. Measurements results - Figure 2 a.

\begin{tabular}{|c|c|c|c|c|c|c|c|c|}
\hline \multicolumn{9}{|c|}{ Infill $60 \%$} \\
\hline \multicolumn{4}{|l|}{ CAD } & \multicolumn{4}{|c|}{ Measurements } & \multirow{2}{*}{ Precision } \\
\hline d & e & h & I & d & e & h & 1 & \\
\hline \multirow{2}{*}{12} & \multirow{5}{*}{15} & \multirow{5}{*}{16,5} & \multirow{5}{*}{15} & 12,05 & 15,02 & 16,56 & 15,03 & High \\
\hline & & & & 11,97 & 15,04 & 16,55 & 15,04 & High \\
\hline 11,9 & & & & 11,88 & 15 & 16,6 & 15,04 & High \\
\hline 11,8 & & & & 11,78 & 15,01 & 16,58 & 15,02 & High \\
\hline 11,7 & & & & 11,64 & 15 & 16,55 & 15,05 & High \\
\hline \multicolumn{9}{|c|}{ Infill 100\% } \\
\hline \multicolumn{4}{|l|}{ CAD } & \multicolumn{4}{|c|}{ Measurements } & \multirow{2}{*}{ Precision } \\
\hline d & e & $\mathbf{h}$ & 1 & d & e & h & 1 & \\
\hline \multirow{2}{*}{12} & \multirow{5}{*}{15} & \multirow{5}{*}{16,5} & \multirow{5}{*}{15} & 11,98 & 15 & 16,52 & 15 & High \\
\hline & & & & 11,97 & 14,98 & 16,53 & 14,99 & High \\
\hline 11,9 & & & & 11,88 & 15,01 & 16,51 & 15,02 & High \\
\hline 11,8 & & & & 11,79 & 15 & 16,52 & 15,01 & High \\
\hline 11,7 & & & & 11,71 & 15,07 & 16,53 & 15,03 & High \\
\hline
\end{tabular}

Table 3. Measurements results - Figure $2 b$.

\begin{tabular}{|c|c|c|c|c|c|c|}
\hline \multicolumn{7}{|c|}{ Infill $60 \%$} \\
\hline \multicolumn{3}{|c|}{ CAD } & \multicolumn{3}{|c|}{ Measurements } & \multirow{2}{*}{ Precision } \\
\hline $\mathbf{f}$ & D & h & f & D & h & \\
\hline \multirow{2}{*}{15} & \multirow{2}{*}{12} & \multirow{2}{*}{16,5} & 15,03 & 11,84 & 16,59 & High \\
\hline & & & 15,02 & 11,83 & 16,6 & High \\
\hline \multicolumn{7}{|c|}{ Infill 100\% } \\
\hline \multicolumn{3}{|c|}{ CAD } & \multicolumn{3}{|c|}{ Measurements } & \multirow{2}{*}{ Precision } \\
\hline $\mathbf{f}$ & D & h & f & D & h & \\
\hline \multirow{2}{*}{15} & \multirow{2}{*}{12} & \multirow{2}{*}{16,5} & 15,08 & 11,65 & 16,51 & High \\
\hline & & & 14,98 & 11,69 & 16,54 & High \\
\hline
\end{tabular}


Table 4. Measurements results - Figure 2 c

\begin{tabular}{|c|c|c|c|c|c|c|}
\hline \multicolumn{7}{|c|}{ Infill $60 \%$} \\
\hline \multicolumn{3}{|c|}{ CAD } & \multicolumn{3}{|c|}{ Measurements } & \multirow{2}{*}{ Precision } \\
\hline d & $\mathbf{h}$ & 1 & d & h & 1 & \\
\hline \multirow{6}{*}{15} & \multirow{6}{*}{16,5} & 9 & 15 & 16,58 & 9,12 & High \\
\hline & & 8,9 & 15,02 & 16,57 & 9,05 & High \\
\hline & & 8,8 & 14,99 & 16,56 & 8,97 & High \\
\hline & & 8,7 & - & - & 8,82 & Low \\
\hline & & 8,6 & 15,03 & 16,54 & 8,74 & High \\
\hline & & 8,5 & - & 16,58 & 8,63 & Low \\
\hline \multicolumn{7}{|c|}{ Infill 100\% } \\
\hline \multicolumn{3}{|c|}{ CAD } & \multicolumn{3}{|c|}{ Measurements } & \multirow{2}{*}{ Precision } \\
\hline d & h & 1 & d & $\mathbf{h}$ & 1 & \\
\hline \multirow{6}{*}{15} & \multirow{6}{*}{16,5} & 9 & 15,02 & 16,53 & 9,14 & High \\
\hline & & 8,9 & 15,04 & 16,52 & 9,07 & High \\
\hline & & 8,8 & 15,02 & 16,54 & 8,88 & High \\
\hline & & 8,7 & 15,05 & 16,54 & 8,76 & High \\
\hline & & 8,6 & 14,85 & 16,56 & 8,72 & Low \\
\hline & & 8,5 & 15,05 & 16,54 & 8,68 & High \\
\hline
\end{tabular}

Table 5. Measurements results - Figure $2 d$

\begin{tabular}{|c|c|c|c|c|c|c|c|c|}
\hline \multicolumn{9}{|c|}{ Infill $60 \%$} \\
\hline \multicolumn{4}{|c|}{ CAD } & \multicolumn{4}{|c|}{ Measurements } & \multirow{2}{*}{ Precision } \\
\hline d & f & $\mathbf{L}$ & h & d & f & $\mathbf{L}$ & h & \\
\hline \multirow{2}{*}{15} & \multirow{2}{*}{12,99} & \multirow{2}{*}{8,99} & \multirow{2}{*}{16,5} & 15,04 & 13,08 & 8,82 & 16,59 & High \\
\hline & & & & 15,01 & 13,07 & 8,85 & 16,58 & High \\
\hline \multicolumn{9}{|c|}{ Infill $100 \%$} \\
\hline \multicolumn{4}{|c|}{ CAD } & \multicolumn{4}{|c|}{ Measurements } & \multirow{2}{*}{ Precision } \\
\hline d & f & $\mathbf{L}$ & h & d & f & $\mathbf{L}$ & $\mathbf{h}$ & \\
\hline \multirow{2}{*}{15} & \multirow{2}{*}{12,99} & \multirow{2}{*}{8,99} & \multirow{2}{*}{16,5} & 15,01 & 13,13 & 8,75 & 16,53 & High \\
\hline & & & & 15,03 & 13,12 & 8,74 & 16,51 & High \\
\hline
\end{tabular}

From Table 2 it can be noticed that for the part presented in Figure 2 a. all values are accurate, for both infill percentages: $60 \%$ and $100 \%$. The part represented in Figure 2 b, whose results are shown in Table 3, is not accurate for any infill percentages. The perfect fit between them, of $0,2 \mathrm{~mm}$, was achieved for diameter $d$ of $11,7 \mathrm{~mm}$ and $11,8 \mathrm{~mm}$ and diameter $D$ of $12 \mathrm{~mm}$ (both infill percentages). From Table 4 it can be seen that for the part illustrated in Figure 2 c. a good accuracy was obtained for diameter $d$ of $15 \mathrm{~mm}$, length $l$ of $16,5 \mathrm{~mm}$ and height $h$ of $8,7 \mathrm{~mm}$. The measurements results of the part represented in Figure 2 d. are shown in Table 5: all of them are inaccurate for both infill percentages. The perfect fit between them, of $0,2 \mathrm{~mm}$, resulted for the pairs: length $l$ of $8,5 \mathrm{~mm}$ and $8,6 \mathrm{~mm}$ with length $L$ of $8,99 \mathrm{~mm}$ (both infill percentages). For the part illustrated in Figure 2 e. it is noted a good dimensional accuracy for diameter $D$ of $4 \mathrm{~mm}$ and length $L$ of $25 \mathrm{~mm}$, for diameter $D$ of $5 \mathrm{~mm}$, all lengths $(15 \mathrm{~mm}, 20 \mathrm{~mm}$ and $25 \mathrm{~mm})$ and for diameter $D$ of $6 \mathrm{~mm}$ 
and length $L$ of $25 \mathrm{~mm}$, all using $60 \%$ infill, while using $100 \%$ infill none of the parts were accurate.

The part shown in Figure $2 \mathrm{f}$. is not accurate for any of the values considered; neither $60 \%$ infill nor $100 \%$ infill.

The part presented in Figure $2 \mathrm{~g}$. is not accurate as well; the results of the measurements are beyond the CAD model for both infill percentages.

The part pictured in Figure $2 \mathrm{~h}$. is inaccurate for $60 \%$ infill because of the length $L$, whose value is well beyond the designed one. For 100\% infill, apart from the length $L$ also the length $L_{l}$ was out of dimensional tolerance, which lead to inaccuracy of the part.

The results of the measurements for the part represented in Figure 2 i. revealed the fact that this is not accurate for the dimensions considered, because of the lengths $L_{2}$ and $L_{3}$, in both cases (infill $60 \%$ and infill $100 \%$ ).

For part in Figure 2 j. eighteen variants were considered, each of them printed three times for both infill percentages, but none of them was accurate. The parts with thickness smaller than $0,5 \mathrm{~mm}$ could not be printed (for none of the infill percentages) and the ones with thickness bigger than $1 \mathrm{~mm}$ exceeded the value from the CAD model.

All the forms printed for the model presented in Figure $2 \mathrm{k}$. are inaccurate, for both infill percentages, all because of exceed values.

For the model in Figure 2 1. only the part having the diameter $\mathrm{g}$ of $2 \mathrm{~mm}$ and the height $h$ of $15 \mathrm{~mm}$ has proved to be dimensional accurate, using $60 \%$ infill, all the other diameters under this value exceeding the CAD dimensions for both infill percentages.

\section{CONCLUSIONS}

The main advantages of 3D printing are single step manufacture, low cost, complexity freedom and design freedom. There are several methods of 3D printing, but the most widely used for plastic materials is Fused Deposition Modeling (FDM). Although FDM is very flexible, the manufacturing of parts is limited by dimension.

The purpose of this paper is to assess the accuracy and the precision for small-sized parts printed on Zortrax M200 3D printer in order to determine the manufacturing limits and restrictions of this technology. In this regard, twelve benchmark models of different sizes with various shapes were considered for this study, which was carried out at the Department of Manufacturing Engineering of the Transilvania University of Brașov.

Keeping a high surface quality and strength and avoiding layer shifting or misalignment, the minimum diameter of the bolt that could be printed was of $3 \mathrm{~mm}$ and the minimum value of the wall thickness was of $0,5 \mathrm{~mm}$ for a certain design.

Regarding the two pairs studied in order to determine the best match between them, after many trials, the value of $0,2 \mathrm{~mm}$ was considered optimal in both cases.

In some cases the results obtained after measuring were the same for both infill percentage $(60 \%$ and $100 \%$ ), leading to the conclusion that infill percentage influences print weight, material usage and productivity.

\section{ACKNOWLEDGEMENT}

This research was funded by the Institutional Development Fund of the Ministry of National Education through the Financial Agreement CNFISFDI 2018-037.

\section{REFERENCES}

[1] Schubert C, van Langeveld M. C, Donoso L. A, Innovations in 3D printing: a 3D overview from optics to organs, Br J Ophthalmol, 98:159-161, 2014.

[2] Huang S H, Liu P, Mokasdar A, Hou L, Additive manufacturing and its social impact: a literature reviw, Int J Adv Manuf Technol, 67:1191-1203, 2013.

[3] Martorelli M, Gerbino S, Lanzotti A, Patalano S, Vitolo F, Flatness, circularity and cylindricity errors in $3 \mathrm{D}$ printed models associated to size and position on the working plane, Eynard, B., Nigrelli, V., Oliveri, S.M., Peris-Fajarnes, G., Rizzuti, S. (eds.) JCM, 2016. LNME, pp. 201-212. Springer, Cham (2007). doi: 10.1007/978-3-319-45781-9_21Google Scholar

[4] [Internet source: https://www.3dhubs.com/knowledge-base/3d-printing-geometry-restrictions (accessed: 10.11.2018)

[5] Milde J, Morović L, The influence of internal structures in fused deposition modeling method on dimension accuracy of components, Research papers of the Faculty of Materials Science and Technology in Trnava, Slovak University of Technology in Bratislava, 24, 73-80, 2016

[6] Internet source: https://zortrax.com/wp-content/uploads/2018/06/Z-ABS_Technical_Data_Sheet_eng.pdf?_ga=2.29795260.202686654.1542284883-19236354.1538763681 (Z-ABS material data sheet, accessed: 03.11.2018)

[7] Internet source: https://all3dp.com/app/uploads/2015/02/zortrax-m200-Data.png (Zortrax M200 3D printer data, accessed: 03.11.2018) 


\section{REZIME}

\section{TEHNOLOŠKE RESTRIKCIJE 3D ŠTAMPE ZORTRAX M200 3D PRINTER}

Cilj istraživanja bio je da se utvrdi tačnost (do kog nivoa 3D štampa odgovara 3D modelu) i preciznost (koja ustanovljava konstantnost merenja) malih plastičnih delova odštampanih na Zortrax M200 3D štapača. Jedan od ciljeva istraživanja bio je i da se utvrdi koliko debljina zida može biti smanjena a da se zadrže tvrdoća i dimenzionalna preciznost. Odgovarajući metod dizajniranja jednog para delova je bio targetiran. Da bi odštampan deo bio odgovarajuće uklopljen sa svojim parom, devijacija fizickih dimenzija je uzeta u obzir. Isto tako, rezultati eksperimentalnog rada na mogućnostima i ograničenjima ove tehnologije štampanja korišteći ovoj štampač su prezentovane u ovom radu. Nekoliko parametara kao što su površinski kvalitet i jačina, menjanje slojeva i neporavnanja su posebno istražena.

Ključne reči: $3 D$ štampanje, modeliranje taloženih depozita, Zortrax M200, minijaturni delovi, tehnološke restrikcije 